\title{
Effect of Coastline Properties and Wastewater on Plankton Composition and Distribution in a Stressed Environment on the North Coast of Olinda-PE (Brazil)
}

\author{
Luci Cajueiro Carneiro Pereira ${ }^{1 *}$, José Antonio Jiménez ${ }^{2}$, Maria Luise Koening ${ }^{3}$, Fernando \\ F. Porto Neto ${ }^{3}$, Carmen Medeiros ${ }^{3}$ and Rauquírio Marinho da Costa ${ }^{4}$ \\ ${ }^{1}$ Laboratório de Oceanografia Costeira e Estuarina; Campus Universitário de Bragança; Universidade Federal do \\ Pará; Alameda Leandro Ribeiro, s/n; Aldeia; 68600-000; Bragança - PA - Brasil. ${ }^{2}$ Laboratori d'Enginyeria \\ Marítima; ETSECCPB; Universitat Politècnica de Catalunya; c/ Jordi Girona 1-3; Campus Nord; ed. D1; 08034 \\ Barcelona - Spain. ${ }^{3}$ Departamento de Oceanografia; Universidade Federal de Pernambuco; Av. Arquitetura, s/n; \\ Campus Universitário; Cidade Universitária; 50739-540; Recife - PE - Brasil. ${ }^{4}$ Laboratório de Plâncton e Cultivo \\ de Microalgas; Campus Universitário de Bragança; Universidade Federal do Pará; Alameda Leandro Ribeiro, s/n; \\ Aldeia; 68600-000; Bragança - PA - Brasil
}

\begin{abstract}
A study of the structure of the plankton community along the coastal zone of the Casa Caiada-Rio Doce area (Pernambuco, Brazil) is presented. The results obtained indicated that in the protected zones the water presented high turbidity, high temperature, low salinity and high nutrient and oxygen rates. All of these conditions were responsible for the reduction in plankton diversity and an increase in the biomass of the most opportunistic ( $r$ strategist) species e.g. Gyrosigma balticum and Bacillaria paxillifera (Phytoplankton) and Euterpina acutifrons (Zooplankton). The differences found with respect to others area studies performed in pristine conditions indicated that plankton structure could be used as an environmental health indicator and that, in this specific area, it was indicative of a poor quality coastal environment.
\end{abstract}

Key words: Plankton, sheltered areas, environmental indicators

\section{INTRODUCTION}

The dynamic structure of plankton communities (diversity, abundance, distribution, temporal changes) depends on the local environmental conditions (e.g. Linden et al., 1992; Shushkina and Vinogradov, 1992; Fernández et al., 1993 and Kokuirkina and Mikaelyan, 1994). In the Pernambuco coast area the structure and characteristics of the planktonic communities have been studied since the 60's by Paranaguá (1966, 1967/69), Eskinazi and Satô (1966), Eskinazi
(1970), Passavante (1979) and Paranaguá et al. (1979), etc. These studies have been focused mainly in estuaries of the littoral and continental shelf of Pernambuco (Fig. 1) reflecting the planktonic structure in relatively pristine areas (considering these areas as zones with a low human influence). In contrast, large variations in diversity, biomass and productivity of the planktonic communities have been observed in stressed environments (e.g. Ottman et al., 1965/66; Eskinazi et al., 1997; Webber and Webber, 1998; Linton and Warner 2003; Koening et al. 2003).

\footnotetext{
${ }^{*}$ Author for correspondence
} 
In the Olinda beaches the main anthropogenic disturbance has been the presence of several groins and breakwaters which were built between 50's and 90's. These structures fully changed the environmental conditions of the zone by creating a highly sheltered area where water renovation has been clearly prevented, specially in comparison with the original conditions.

To assess how the typical planktonic communities could be altered/conditioned by perturbations introduced by man in the coastal zone, such as alterations of the coastal configuration e.g. construction of structures modifying the nearshore hydrodynamics and sediment transport and as a result, changing the coastal "shape", (see, Pereira, et al. 2000; Pereira, 2001 and Pereira et al., in Press) and degradation of the environmental conditions e.g. sewage outfalls with the consequent water pollution (see, Pereira, et al., 1996; Pereira et al. 2003a and Pereira et al., 2003b), a study was undertaken in a highly stressed coastal area of Olinda. Thus, the aim of this study was to characterize the structure of the planktonic communities along the coastal zone of the Casa Caiada-Rio Doce area and to relate them to the natural and anthropic environmental conditions. This is an important issue in assessing the status of the area, due to the key role of the plankton in the marine food chain. Assuming that the plankton must directly reflect the health of the area, it should be used as an environmental indicator (Haikui and Jiachong, 1992; Rosenstrom and Lepisto, 1996; Stemberg and Miller, 1998, Linton and Warner, 2003).

\section{MATERIAL AND METHODS}

The study area was the Casa Caiada-Rio Doce beach complex, a $4.5 \mathrm{~km}$-long sandy coastline located at the northern end of Olinda City (Pernambuco, NE Brazil) (Fig. 1). The characteristics of this coastal area were determined, first by those of the surrounding coastal sea and second, by the potential influence of urban activities. In this way, the environmental status of this area could be used to "track" the human influence on a "natural" system.

The present beach configuration was the result of the construction of several structures along the coast that were built to mitigate and prevent shoreline erosion problems occurring in the area since the 70's. Thus, the originally open beach is now protected by seven detached (parallel) breakwaters and two terminal groins at its ends, delimiting three main "bays" (Fig. 1).

The local maximum depths in the sheltered zone were $4.0 \mathrm{~m}$ (bay 1), $1.5 \mathrm{~m}$ (bay 2) and $0.5 \mathrm{~m}$ (bay 3) with respect to the low tide. Due to the protective effect of the structures against the waves, water renovation in the protected area was mainly controlled by tidal currents (Pereira, 2001 and Pereira et al. 2004). The tides in the area were semidiurnal with average height of $2.10 \mathrm{~m}$ (DHN / Tide table - Recife's Harbour).

Two field campaigns were undertaken to characterize the structure of the planktonic communities in the area, one during the wet season in July/1998 and the other during the dry season in February/1999. In each campaign, physical (wind, wave, tide and currents), chemical (hydrological) and biological (plankton) variables were measured in the sheltered areas (shoreward of the breakwaters) and open waters (seaward of the breakwaters) during spring tidal phases, i.e. flood and ebb tides (see Fig. 1 for measurement locations). Hydrological measurements and plankton sampling were performed in the same stations (Fig. 1). Meteorological data were recorded using a Testo Term (Testo-440) anemometer in six stations throughout the study area (Fig. 1), complemented by precipitation and evaporation data obtained from the Brazilian National Institute of Meteorology.

Hydrological data were obtained from the analysis of water samples collected with Nansen oceanographic bottles and temperature sensor. The main variables determined were suspended particulate material, dissolved oxygen, salinity and dissolved nutrients (nitrite, nitrate, phosphate and silicate). Water samples were filtered through a glass microfibre filter $(\mathrm{GF} / \mathrm{C})$ to determine suspended particulated material. Salinity was determined by the Morh-Knudsen method, described by Strickland and Parsons (1972), dissolved oxygen by the Winkler method, described by Strickland and Parsons (1968) and dissolved nutrient salts according to Strickland and Parsons (1972) and Grasshoff et al. (1983). Surface current velocities were measured with a Sensordata SD30 currentmeter at 23 stations covering the study area (Fig. 1). Simultaneously, local water levels were controlled by graduated poles located in each bay. A non-parametrical statistical test (Wilcoxon) was performed to examine the significance of differences in 
hydrological data between wet and dry seasons, high and low tides and inshore and offshore sites. To characterize the distribution and composition of the plankton organisms greater than $65 \mu \mathrm{m}$, surface samples of two plankton size groups were processed by filtration of 2001 of water collected with plastic buckets through nets with mesh sizes of $65 \mu \mathrm{m}$ and $300 \mu \mathrm{m}$. The plankton was conditioned in plastic bottles and preserved in 4\% buffered formaline (Newell and Newell, 1963). In laboratory, samples of sizes $>65 \mu \mathrm{m}$ and $>300 \mu \mathrm{m}$ were filtered and weighed to determine the biomass (Omori and Ikeda, 1984).

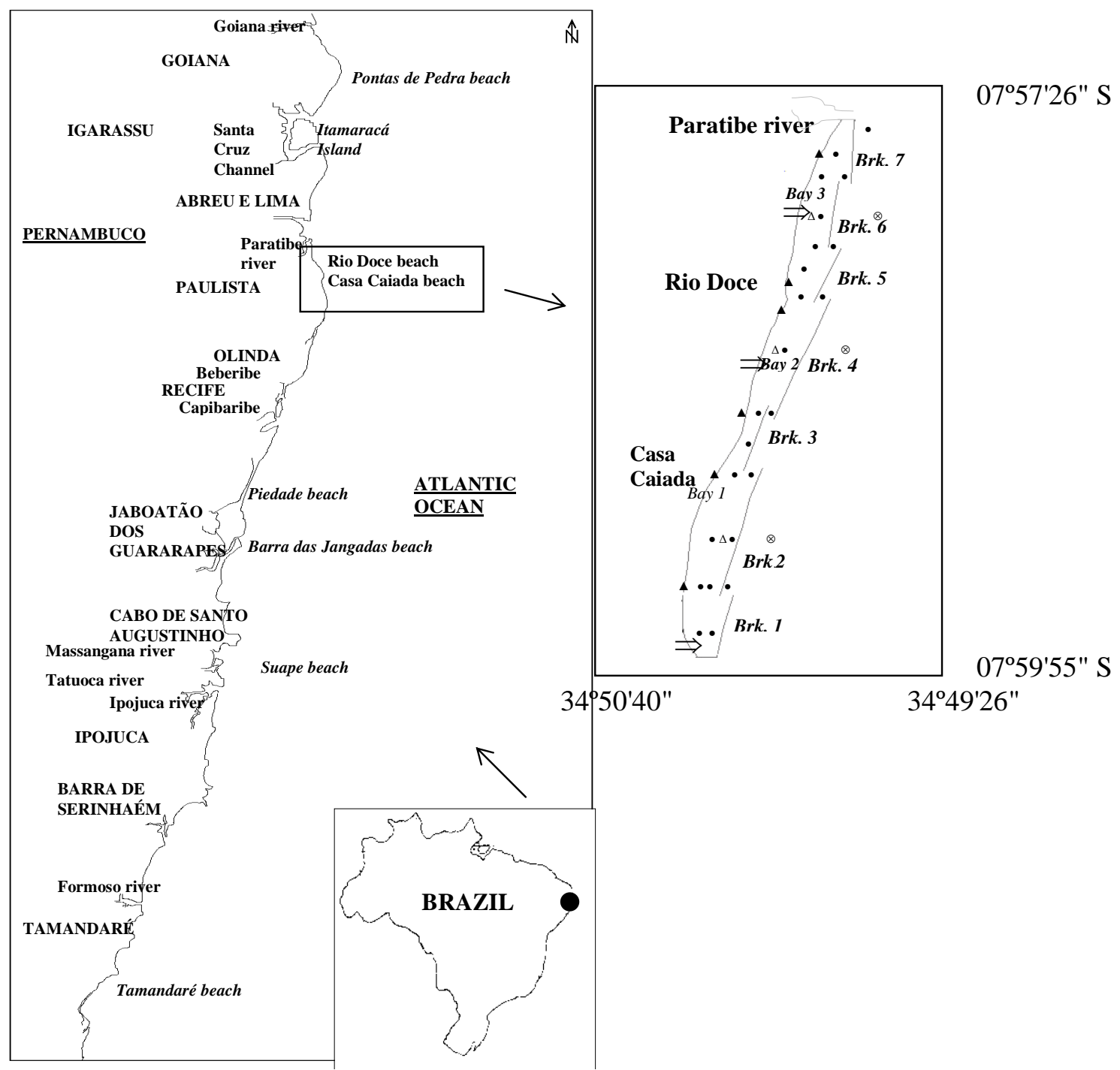

Figure 1 - Pernambuco coast and area of study showing measurement locations: • currents, meteorological stations, $\Delta$ (inshore) and $\otimes$ (offshore) hydrological and biological sampling stations, $\Rightarrow$ domestic sewage outfalls, Brk Breakwater.

A mesh of $300 \mu \mathrm{m}$ to separate the organisms of the macrozooplankton collected in the nets with mesh sizes of $65 \mu \mathrm{m}$ was used. For zooplankton organisms between $65-300$ three aliquots $(1 \mathrm{ml})$ from each sample were analyzed in a SedgwickRafter chamber under a stereoscopic microscope.
For zooplankton analysis (> $300 \mu \mathrm{m}$ ) all individuals (entire sample) were examined, counted and keyed to different taxonomic categories under a stereoscopic microscope. Some zooplanktonic individuals were identified to species level, while others were usually keyed to 
family, order or class categories, according to Boltovskoy (1981), Matsumura-Tundisi (1986), Cristi (1986) and Todd and Laverack (1991).

The floristic composition was based on identification of the specific and infra-specific taxa. For the quali-quantitative studies, sub samples of $0.5 \mathrm{ml}$ were observed in a SedgwickRafter chamber under a Zeiss compound microscope. Permanent slides were made for confirmation of diatom species (Muller-Melchers and Ferrando, 1956). The classification scheme followed Desikachary (1959), Prescott (1975), Hasle (1983), Round et al. (1990), Lange et al. (1992) and Thomas (1997). The quantitative data were used to calculate the relative abundance (percentage of the total number of organisms of each taxon in the sample in relation to the total number of organisms in the sample), frequency of occurrence (percentage of samples in which each organism occurred in relation to the total number of samples) and density (total numbers of organisms per volume).

The diversity index (Shannon, 1948) and evenness (Pielou, 1969, 1977) were calculated to determine the structure of the plankton communities:

a) Diversity index, $\mathrm{H}^{\prime}$

$$
\mathrm{H}^{\prime}=-\sum_{i=1}^{S} p_{i} \log _{2} p_{i}
$$

where $S$ is total number of species, $p i$ is the proportion of the number of individuals of species $n i$ to the total number of individuals $(p i=n i / N), N$ is the total number of individuals and $n_{1}, n_{2}, \ldots$, are the respective numbers of individuals of each species.

\section{b) Evenness,}

$$
\mathrm{J}=\mathrm{H}^{\prime} / \log _{2} \mathrm{~S}
$$

The evenness, varying between 0 and 1 , indicates the degree of equitability of the community.

A non-parametrical statistical test (KolmogorovSmirnov) was performed to examine the significance of differences in plankton density data between wet and dry seasons, high and low tides and inshore and offshore sites.

\section{RESULTS}

\section{Hydrodynamics}

The presence of the breakwaters along the study area shelters from wave action, preventing its significant role in water renovation in the bays. During the field campaign, wave conditions were characterized by wave heights lower than $0.3 \mathrm{~m}$ and $0.2 \mathrm{~m}$ in bays 1 and 3, respectively. These low-energy wave conditions, together with the effects of the breakwaters, could be used to characterize as quasi-negligible the role of the waves in water circulation in the bays during the experiments. It demonstrated that in general, the strongest currents are found as expected at breakwater gaps. In general, the strongest currents were recorded during the February campaign, although recorded wind speeds (NE-E, $3.53 \mathrm{~m} \mathrm{~s}^{-1}$ ) were lower than those corresponding to the July experiment (SE, $4.26 \mathrm{~m} \mathrm{~s}^{-1}$ ). This stresses the dominance of tidal forcing on the coastal circulation over wind-induced circulation, since in the February sampling the tide amplitude was larger than that of July.

\section{Hydrographic Parameters}

The hydrographic conditions, i.e. physico chemical water properties of the study area showed strong seasonal changes due to the very well-defined seasonal structure of the environmental conditions (precipitation and insolation rates) and the physical constraints of the study area (low water renovation rates in the sheltered zone owing to the presence of breakwaters). During the wet period, the study area presented the lowest recorded values of salinity and temperature. In general, changes in water properties were recorded in the sheltered zone (i.e. landwards of the breakwaters) where urban outfalls directly discharged. These freshwater discharges, together with the low water renovation rates, the high precipitation rates and the low evaporation rates, were responsible for a decrease in water salinity, reaching maximum values of 35.58 s.p. and maximum temperature values of $28.34{ }^{\circ} \mathrm{C}$ in the sheltered zone (bay 3). This season also recorded the highest oxygen concentrations (with a maximum of $7.22 \mathrm{ml}^{-1}$ ) and greatest water turbidity, with maximum suspended particulate water concentrations of 0.0193 g. $1^{-1}$ again in the sheltered zone (bay 3 ). During this period, they were registered the 
highest nutrient concentrations, except to nitrite (Fig. 2).

During the dry season, the study area presented the highest recorded values of salinity and temperature. Again, the sheltered zone showed the highest values, mainly due to the low water renovation. The decrease in freshwater discharge and the high insolation rates caused this area to present the highest water salinity (maximum values of 36.6 s.p.) and temperature (maximum values of $32.4{ }^{\circ} \mathrm{C}$ ) in the sheltered zone (bay 3 ). The environmental conditions during this period were responsible for high oxygen concentrations with a maximum of $6.8 \mathrm{mll}^{-1}$ and lowest suspended particulate matter concentrations with maximum values of $0.017 \mathrm{g.l} \mathrm{l}^{-1}$, both in the sheltered zone (bay 3) (Fig. 2). The lowest nutrient concentrations were registered during this period, except to nitrite (Fig. 2).

There were significant differences $(p<0.01)$ between the temperature measured during the wet and dry seasons, high and low tides and inshore and offshore sites. On the other hand there were significant differences $(\mathrm{p}<0.01)$ for salinity, suspended particulate, nitrate and phosphate obtained during the wet and dry seasons.

\section{Plankton Biomass}

Fig. 3 shows the total biomass of organisms in the study area during the experiments. In general terms, the highest biomass values were found during the wet season in the sheltered zone. During this season, the highest values were found for plankton between $65-300 \mu \mathrm{m}$ in bay 3 (17500 $\left.\mathrm{mg} \cdot \mathrm{m}^{-3}\right)$ and bay 1 (11800 mg. $\left.\mathrm{m}^{-3}\right)$ at low tide (inshore location). These locations are characterized by the presence of domestic sewage outfalls. Additionally, bay 3 was influenced by discharges of the Paratibe river.

During the dry season, the highest biomass values were reported for plankton $>300 \mu \mathrm{m}(>8000$ $\mathrm{mg} \cdot \mathrm{m}^{-3}$ ) in the northern part of the beach (bays 2 and 3), at low tide in the offshore locations (seaward of the breakwaters).

\section{Phytoplankton}

The phytoplankton organisms recorded in the study area during the experiment were Cyanophyceae, Euglenophyceae, Dinophyceae, Bacillariophyceae and Chlorophyceae. The
Bacillariophyceae were dominant, with a relative abundance (percentage of the total number of organisms of each taxon in the sample in relation to the total number of organisms in the sample) of $90.2 \%$ and $71.8 \%$, during the wet and dry seasons respectively (Table 1). The total number of species recorded throughout all the experiments was 59. During the wet season, the highest densities of organisms were found at low tide in the sheltered zone of Rio Doce (bay 3) with maximum values of $5.0 \times 10^{8}$ cell. $\mathrm{m}^{-3}$. At high tide, concentration values were almost uniform throughout the area, except for the sheltered zone of bay 1 , where a peak of $3.1 \times 10^{8}$ cell. $\mathrm{m}^{-3}$ was detected (Fig. 3). The species with the highest densities (considering all the stations) were Gyrosigma balticum and Bacillaria paxillifer. During this season, 42 of the total 59 recorded species were found, the most frequent (the percentage of samples in which each organism occurred in relation to the total number of samples) being Gyrosigma balticum (91\%), Fragilaria capucina (75\%), Coscinodiscus sp. (58\%), Bacillaria paxillifera $(50 \%)$ and Asterionellopsis glacialis (42\%).

The diversity in terms of information content was systematically higher in the offshore locations (seaward of the breakwaters) than those of the corresponding inshore areas. Diversity values increased northwards (from bay 1 to bay 3), with minimum values of 0.92 bits.ind $^{-1}$ and 2.0 bits.ind $^{-1}$ in the inshore and offshore sites, respectively and maximum values of 2.1 bits.ind $^{-1}$ and 3.48 bits.ind $^{-}$ ${ }^{1}$ in the inshore and offshore sites, respectively (Fig. 4). Because equitability increased with the peaks of species diversity and/or number of species, the highest values were found in the offshore zone increasing from bay 1 to bay 3 (Fig. 4). The minimum values were registered in the inshore locations $(0.47$ - high tide and 0.39 low tide) (Fig. 4).

During the dry season, only 28 of the total 59 recorded species were found. The highest densities of organisms were registered at low tide in the sheltered areas of bays 1 and 2, with maximum values of $0.66 \times 10^{8}$ cell. $\mathrm{m}^{-3}$ and $0.67 \times 10^{8}$ cell. $\mathrm{m}^{-3}$, respectively. In the offshore area, a maximum density of $0.78 \times 10^{8}$ cell. $\mathrm{m}^{-3}$ was registered in bay 3 at high tide (Fig. 3). The species with the highest densities were Protoperidinium sp. and Heliotheca thamensis. 

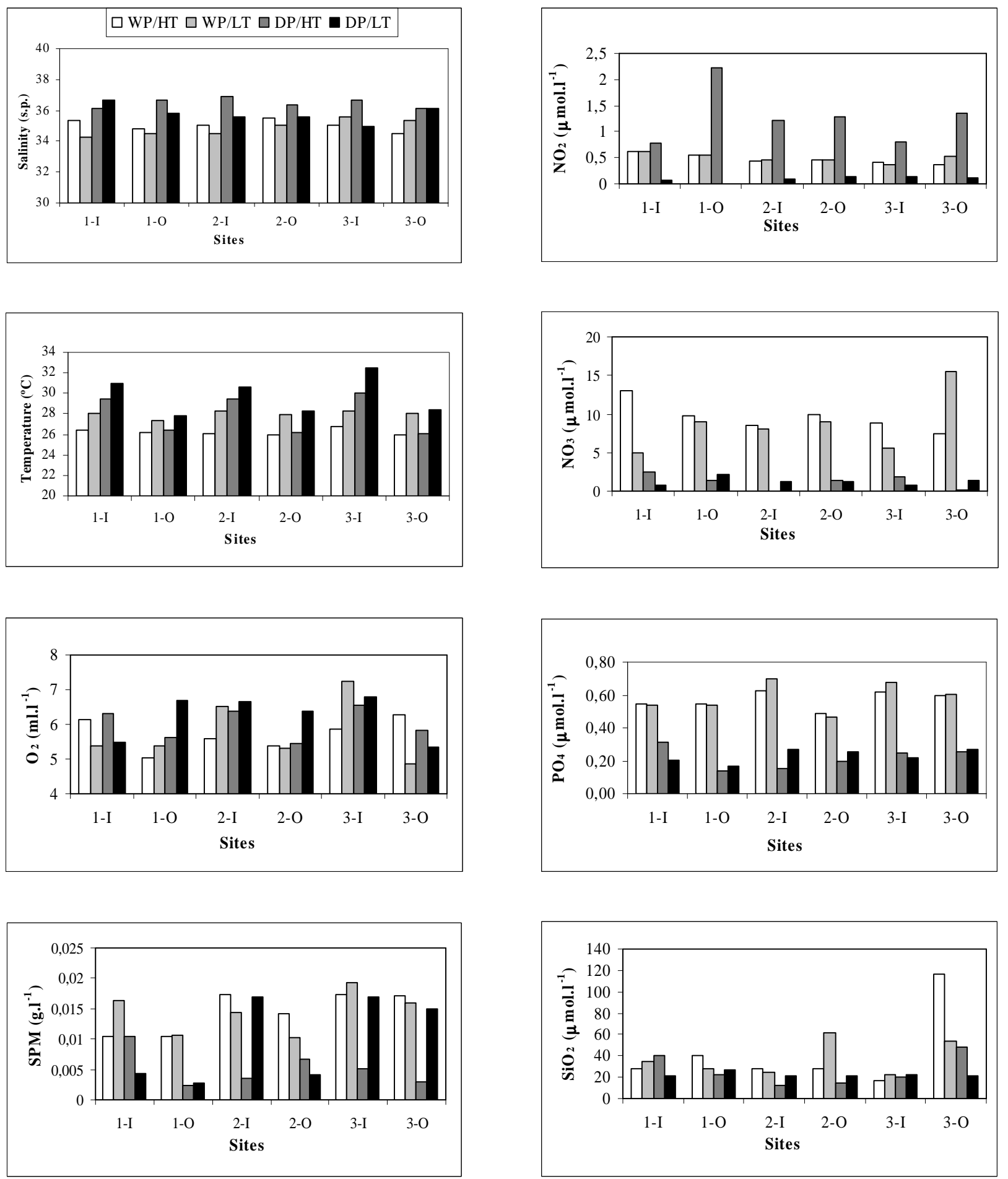

Figure 2 - Variation of salinity, temperature, dissolved oxygen, suspended particulate material (SPM) and nutrient salts (nitrite- $\mathrm{NO}_{2}$, nitrate- $\mathrm{NO}_{3}$, phosphate- $\mathrm{PO}_{4}$ and silicateSiO 2 ) in Casa Caiada and Rio Doce. (HT: high tide, LT: low tide, DP: dry period, WP: wet period, I: inner locations - landward of breakwaters, O: outer locations - seaward of breakwaters, 1: Bay 1, 2: Bay 2, 3: Bay 3). 
The most frequent species were Protoperidinium sp. (80\%), Thalassiosira sp. (70\%), Chaetoceros teres (70\%), Gyrosigma balticum (70\%), Heliotheca thamensis (60\%) and Euglena acus $(40 \%)$. The highest diversity was found in the inshore area (with the exception of bay 3 at high tide). Diversity values increased southwards (from bay 3 to bay 1) with minimum values of 1.18 bits.ind $^{-1}$ and 1.25 bits.ind $^{-1}$ and maximum values of 3.23 bits.ind $^{-1}$ and 2.93 bits.ind $^{-1}$ for the inshore and offshore sites respectively (Fig. 4). The highest equitability values during the dry season were found in the inshore area, increasing from bay 3 to bay 1 with minimum value of 0.89 and maximum ones of 0.98 during the high tide (Fig. 4). There were significant differences $(p<0.05)$ between the phytoplanktonic density obtained during the wet and dry seasons, high and low tides and inshore and offshore sites.

\section{Zooplankton}

Copepods were the most abundant zooplankton organisms recorded, followed by foraminiferans and tintinninids groups (Table 1). During the wet period, the highest densities of zooplankton between $65-300 \mu \mathrm{m}$ were found in the offshore area of Casa Caiada at low tide $\left(3.6 \times 10^{8}\right.$ org. $\left.\mathrm{m}^{-3}\right)$ and Rio Doce (bay 2) at high tide $\left(4.1 \times 10^{8}\right.$ org. $\left.\mathrm{m}^{-3}\right)$ (Fig. 3). The species with higher abundances were Oithona hebes and Leprotintinnus nordqvisti. The zooplankton $>300 \mu \mathrm{m}$ showed a similar pattern of concentration throughout the study area, the offshore zone of Casa Caiada (bay 1) being the site with the highest value $\left(8.6 \times 10^{5}\right)$ (Fig. 3). The species with higher densities were Parvocalanus crassirostris and Oithona hebes. The higher frequencies of occurrence of zooplankton between $65-300 \mu \mathrm{m}$ were observed for Favella ehrenbergii (100\%), copepods (nauplii) (100\%), Oithona hebes (100\%), Leprotintinnus nordqvisti (92\%), gastropods (veliger) (83\%), other foraminiferans (83\%), bivalves (veliger) $(75 \%)$, Parvocalanus crassirostris (75\%) and Textularia sp. $(75 \%)$. For the zooplanktonic $>300 \mu \mathrm{m}$, the higher frequencies were observed for Parvocalanus crassirostris $(50 \%)$, other foraminiferans $(42 \%)$, nematods (42\%), Oithona hebes $(42 \%)$ and other haparcticoids $(42 \%)$. The highest diversity during the wet period was generally found in the sheltered zone for zooplankton between $65-300 \mu \mathrm{m}$, with the exception of bay 1 at low tide and in the offshore area at high tide for the zooplankton $>300 \mu \mathrm{m}$. Minimum diversity values of 1.10 bits.ind $^{-1}$ and 1.44 bits.ind $^{-1}$ and maximum of 3.2 bits.ind $^{-1}$ and 3.0 bits.ind $^{-1}$ were found in the inshore and offshore sites, respectively for the zooplankton between 65 - $300 \mu \mathrm{m}$ (Fig. 4).

The highest values of equitability were found in the inshore area of bay 2 in the landward area for zooplankton between $65-300 \mu \mathrm{m}$ and in the offshore area for zooplankton $>300 \mu \mathrm{m}$. For zooplankton between $65-300 \mu \mathrm{m}$, minimum equitability values were found for the offshore sites, mainly during high tide (0.23) (Fig. 4). For zooplankton > $300 \mu \mathrm{m}$, minimum equitability values were found for the offshore sites (0.69 high tide and 0.73 - low tide) (Fig. 4).

During the dry season, the highest density of zooplankton between $65-300 \mu \mathrm{m}$ was found in the offshore area of Casa Caiada, at low tide $\left(1.9 \times 10^{8}\right.$ org. $\left.\mathrm{m}^{-3}\right)$ (Fig. 3$)$. The species with the highest densities were Leprotintinnus nordqvisti and Favella ehrenbergii.

The species with the highest concentration was Oikopleura dioica. The higher frequencies of occurrence of zooplankton between $65-300 \mu \mathrm{m}$ were observed for Favella ehrenbergii (100\%), copepods (nauplii) (100\%), Leprotintinnus nordqvisti (100\%), Oikopleura dioica (91\%), Euterpina acutifrons (73\%), gastropods (veliger) (73\%), Oithona hebes $(73 \%)$ and other foraminiferans $(73 \%)$. For the zooplankton $>300$ $\mu \mathrm{m}$, higher frequencies of occurrence were found for copepods (nauplii) (100\%), Oikopleura dioica (73\%), Euterpina acutifrons (63\%) and other haparcticoids $(45 \%)$. During this period, the diversity was highest in bay 1 for zooplankton between $65-300 \mu \mathrm{m}$ (high tide) and increased northwards (from bay 1 to bay 3 ) to the zooplankton > $300 \mu \mathrm{m}$. For the zooplankton between $65-300 \mu \mathrm{m}$, minimum values of 1.1 bits.ind $^{-1}$ and 1.34 bits.ind $^{-1}$ and maximum values of 2.8 bits.ind $^{-1}$ and 2.25 bits.ind $^{-1}$ were found for the inshore and offshore sites, respectively (Fig. 4). For the zooplankton $>300 \mu \mathrm{m}$, minimum values of 0.91 bits.ind $^{-1}$ and 1.34 bits.ind $^{-1}$ and maximum values of 2.28 bits.ind $^{-1}$ and 2.14 bits.ind $^{-1}$ were found for the inshore and offshore sites, respectively (Fig. 4). Higher equitability values were found in bay 1 (high tide) for zooplankton between $65-300 \mu \mathrm{m}$ and the highest in bays 2 and 3 for the zooplankton $>300 \mu \mathrm{m}$. 

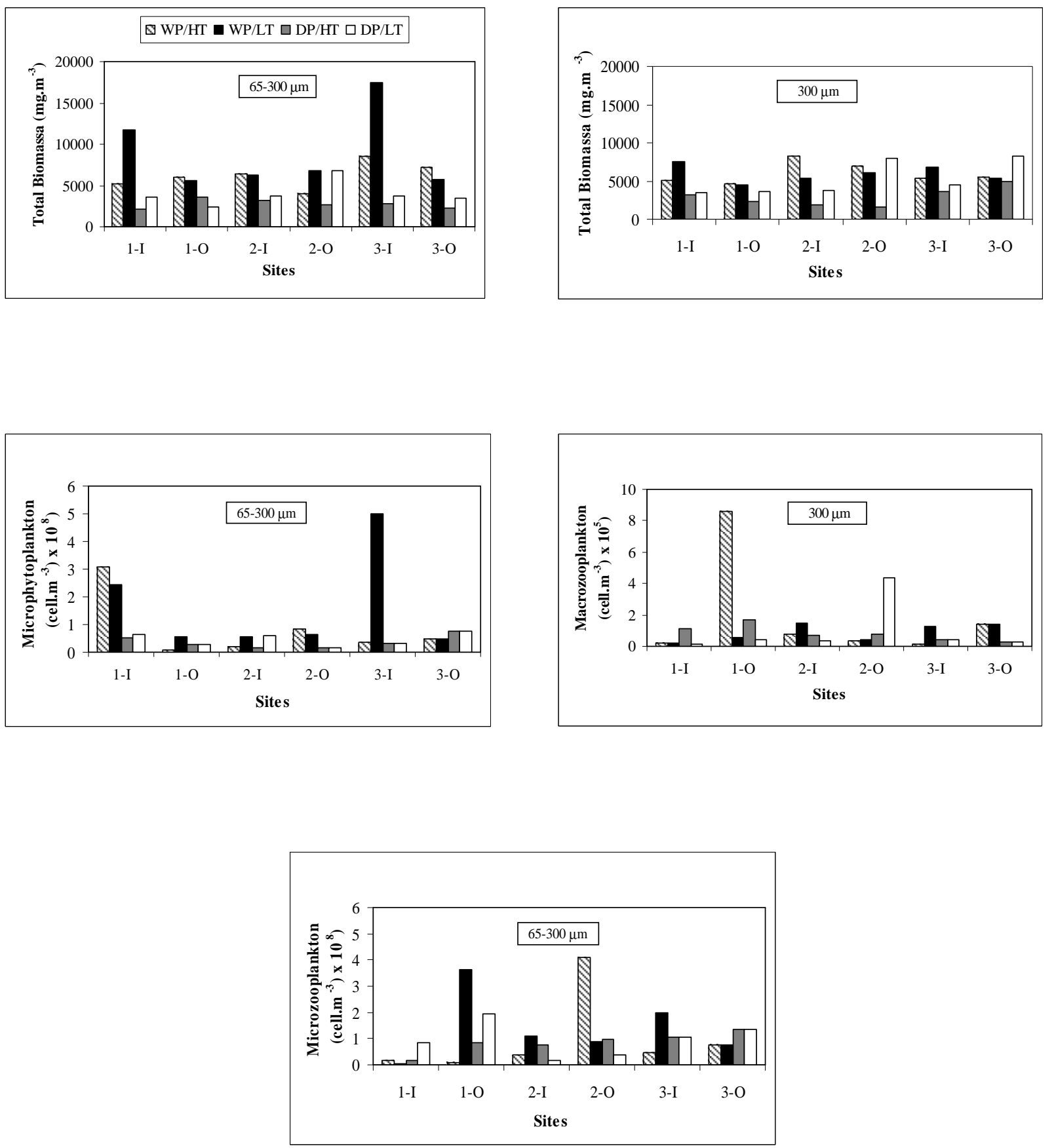

Figure 3 - Total biomass of plankton and total number of organisms per volume of phytoplankton and zooplankton. (HT: high tide, LT: low tide, DP: dry period, WP: wet period, I: inner locations - landward of breakwaters, O: outer locations - seaward of breakwaters, 1: Bay 1, 2: Bay 2, 3: Bay 3). 
Table 1 - Relative abundance of the main phytoplankton and zooplankton groups in Casa Caiada and Rio Doce beaches, during the wet and dry seasons.

\begin{tabular}{lccc}
\hline Phytoplankton & Net Size $(\boldsymbol{\mu m})$ & Wet season (\%) & Dry season (\%) \\
\hline Cyanophyceae & 65 & 7.5 & 4.8 \\
Euglenophyceae & 65 & 1.3 & 2.7 \\
Dinophyceae & 65 & 0.7 & 19.7 \\
Bacillariophyceae & 65 & 90.2 & 71.8 \\
Chlorophyceae & 65 & 0.3 & 1.1 \\
\hline Zooplankton & Net Size $(\boldsymbol{\mu m})$ & Wet season $(\%)$ & Dry season (\%) \\
\hline Foraminifera & 65 & 11.1 & 1.7 \\
& 300 & 13.5 & 0.0 \\
Tintinnina & 65 & 17.8 & 12.1 \\
& & & Cont. Table 1 \\
Cont. Table 1 & & & \\
& 300 & 2.3 & 0.0 \\
Copepoda & 65 & 57.2 & 79.5 \\
& 300 & 48.9 & 71.2 \\
Others crustacean & 65 & 0.8 & 0.0 \\
Others & 300 & 6.9 & 7.2 \\
& 65 & 13.1 & 6.7 \\
\hline \hline
\end{tabular}
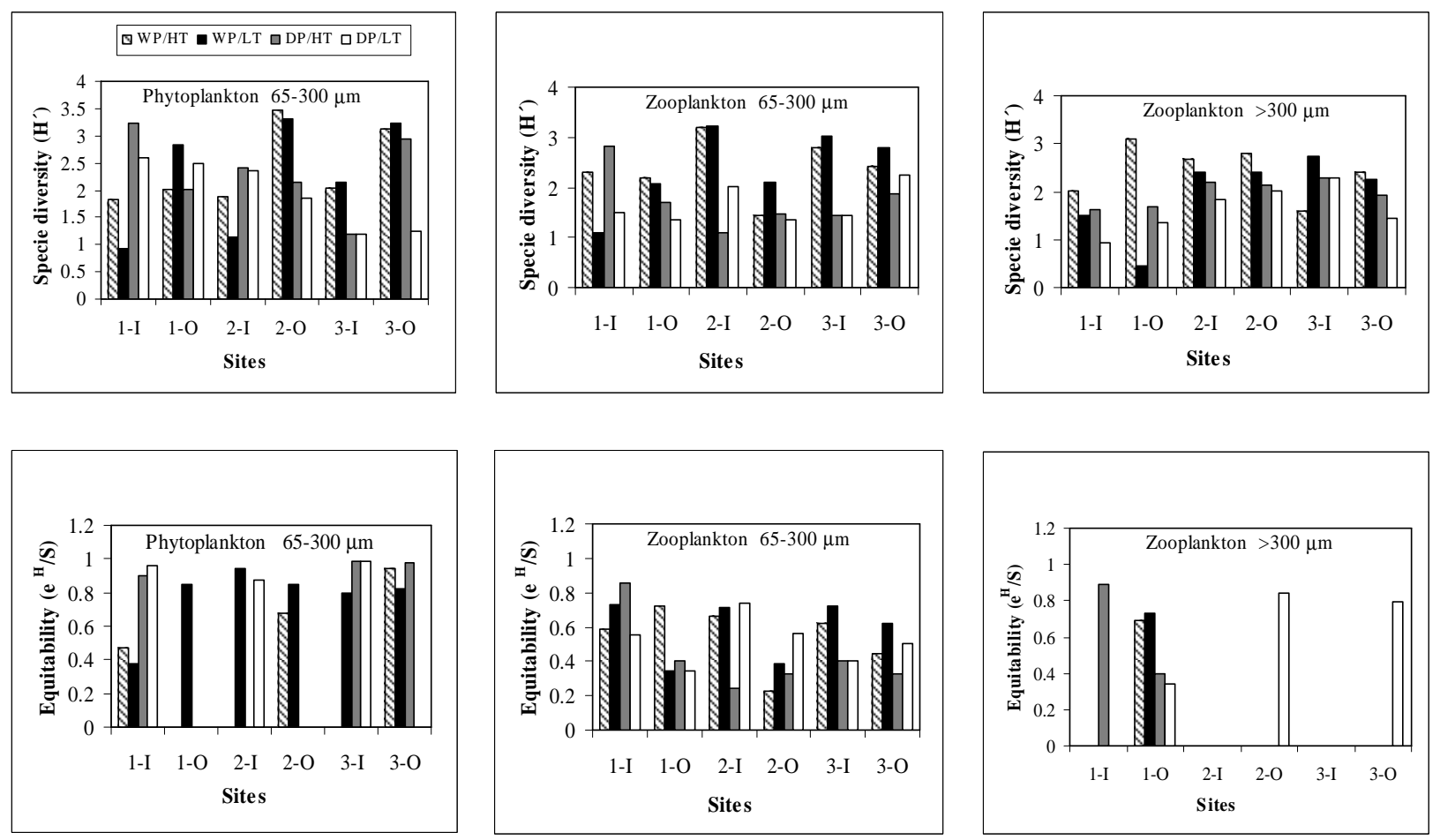

Figure 4 - Species diversity and equitability of the plankton registered in Casa Caiada and Rio Doce. (HT: high tide, LT: low tide, DP: dry period, WP: wet period, I: inner locations landward of breakwaters, O: outer locations - seaward of breakwaters, 1: Bay 1, 2: Bay 2, 3: Bay 3).

For zooplankton between $65-300 \mu \mathrm{m}$, minimum equitability values of 0.24 and 0.32 and maximum values of 0.85 and 0.74 were found in the inshore and offshore sites, respectively (Fig. 4). For 
zooplankton > $300 \mu \mathrm{m}$, the equitability varied from 0.34 (low tide) to 0.89 (high tide) (Fig. 4).

There were significant differences $(\mathrm{p}<0.05)$ between the zooplanktonic density $(65-300 \mu \mathrm{m})$ obtained during the wet and dry seasons, high and low tides and inshore and offshore sites. Similar results were found for the zooplanktonic density ( $>$ $300 \mu \mathrm{m})$.

\section{DISCUSSION}

The present configuration of the beach, with seven detached breakwaters, is the main cause of the hydrodynamic regime, characterized by an environment sheltered from wave action (which is the main source of water renovation in the coastal zone) with circulation being induced mainly by tidal forcing, and usually characterized by weak currents reaching their maximum intensities at breakwater gaps. In addition to this, the presence of the Paratibe river and several domestic sewage outfalls also contribute significantly to the specific water characteristics in the study area. The peaks of some nutrients during the wet season are a consequence of these continental discharges. The high nitrite concentrations observed during the dry season probably result from the preference of phytoplanktonic organisms in the assimilation of other nitrogen forms such as ammonia and nitrate.

During the wet period differences in nutrient concentration are not so evident because primary production is not very effective, so high concentrations could be observed for all nutrients. Temporal changes in the distribution and abundance of plankton may be caused by variations of many abiotic and biotic factors. In Pernambuco, the distribution of plankton is regulated mainly by eutrophication, river discharges, hydrology, tidal stage, precipitation and grazing (Paranaguá, 1985/86, NeumannLeitão et al., 1991/93 and Eskinazi et al., 1997). Some research done in other coastal zones have identified the role of wind effects (Gómez-Erache et al., 2000), tidal influence (Villate, 1997), atmospheric pressure, current speed and direction, water temperature (Licandro and Ibanez, 2000) and seasonal changes (Khalil and El-Rahman, 1997; Villa et al., 1997 and Totti et al., 2000) to control the distribution and composition of plankton communities.

In the study area, the observed distribution pattern was mainly conditioned by precipitation and evaporation rates, nutrient concentrations, temperature, salinity and tidal stage patterns. During the wet season, the increase in freshwater input to the bays due to high precipitation, river discharges and sewage outfalls resulted in a decrease in salinity and an increase in nutrient concentrations and turbidity. These conditions caused an increase in the phytoplankton density and Ulva lactuta macroalgae (Pereira et al., 2003b) and consequently an increase in the oxygen production during the day, in the sheltered zone at low tide (bay 3). The effect of the tidal stage during this period was observed at flood tide, when "new" seawater was introduced into the sheltered area, which seemed to induce a decrease in nutrient concentration and phytoplankton density. During the dry season, the decrease in freshwater discharge and the high insolation rates resulted in salinity and temperature increases, and a decrease in nutrient concentration and turbidity, resulting in a decrease of the phytoplankton density.

High densities of opportunistic (r-strategist) species and extreme values of abiotic parameters were found at low tide and in the sheltered areas, mainly in Rio Doce (bay 3) being this the most impacted area. The influence of the Paratibe river and several domestic sewage outfalls and the low water circulation due to the presence of coastal protection structures were the principals responsible by the stressed environment condition on the north coast of Olinda. Similar results have been found by Eskinazi et al. (1997) and Koening et al. (2003) near Recife and Suape harbors, respectively, under the influence of similar environmental conditions (freshwater and sewage outfalls) and by Koening and Eskinazi (1991) and Moura (1992) in other coastal zones along Pernambuco coast.

The diversity and equitability values should reflect the current environmental conditions. Diversity indicates the degree of complexity of the community structure. It is a function of two elements, one being the number of species (richness), and the other the equitability (evenness) with which individuals are distributed among species (e.g. Omori and Ikeda, 1984). Thus, high values should indicate the presence of "stable" and "pristine" conditions. High diversity values have been recorded along the Pernambuco coast in several environments such as the coastal zone (Nascimento-Vieira et al., 1985/86 and NeumannLeitão et al., 1991/93), the estuarine zone 
(Neumann-Leitão et al., 1994/95, Almeida et al., 2003) and the oceanic zone (Gusmão et al., 1997). In the study area, the influence of freshwater discharges (including sewage outfalls) and the instability of water properties (due to the major variation induced by seasonal changes and by the physical constraint imposed by the breakwaters) have caused at a diversity reduction $\left(\mathrm{H}^{\prime}\right)$ in the phytoplankton, mainly in the sheltered zone in Rio Doce. Due to this, the study area showed low diversity values (in general, lower than 3.0 bits.ind ${ }^{-1}$ ) and equitability (generally lower than $0.5)$. Environmental variability was the principal factor influencing the lowest diversity values in the Solís Grande estuary (Gómez-Erache et al., 2000) in copepod organisms (lower than 1.5) and on the south coast of Portugal (Villa et al., 1997), in phytoplankton and zooplankton communities (lower than 1.8).

At Casa Caiada and Rio Doce beaches, the copepods were the most representative group, Oithona hebes, Parvocalanus crassirostris and Euterpina acutifrons being the most abundant and frequent species. Similar results were observed by Neumann-Leitão et al. (1991/93), who suggested that the predominance of these species was a consequence of their herbivore feeding pattern and opportunistic behavior in eutrophic conditions. $E$. acutifrons has also been reported by Botovoskoy (1981) as an indicator of eutrophic environments. The tintinnids were the second principal group and Leprotintinnus nordqvisti and Favella enhrenbergii were the most frequent and abundant species. These species were typical of coastal and estuarine waters (Raymont, 1983) and presented eurythermic and euryhaline characteristics (Nascimento-Vieira et al., 1985/86), which explained their abundance in the study area.

Previous work on the continental shelf of Pernambuco and coastal areas not impacted by humans (e.g. Nascimento Vieira et al., 1985/86, Neumann-Leitão et al., 1991/93 and Silva et al., 2003) could be taken as a reference for the zooplankton structure in the study area under "pristine conditions". These studies found that copepods were the most abundant group of zooplankton organisms, with tintinnids, chaetognatha and foraminiferans also being representative. Thus, copepods showed a high diversity and the most frequent species were Acartia lilljeborgii, Parvocalanus crassirostris, Calanopia americana, Centropages velificatus, Euterpina acutifrons, Macrosetella gracilis,
Temora stylifera, Corycaeus sp., Microsetella sp., Oncaea sp. and Oithona sp.

The maximal peaks of zooplankton in the seaward of the breakwaters could be a consequence of the herbivore/detrivorous feeding pattern. On the other hand, low diversity and high density of some opportunistic (r-strategist) species (e.g. Euterpina acutifrons) could be a result of the eutrophic condition (Webber and Webber, 1998 and Linton and Warner, 2003).

The most representative phytoplankton species were Gyrosigma balticum, Bacillaria paxillifera and Chaetoceres teres, amongst others. $G$. balticum was cited by Eskinazi and Koening $(1985 / 86)$ as an estuarine species (brackish water), restricted to a mesohaline environment, which explained its abundance near the Paratibe river. The dominance of diatoms could be explained by the tolerance of the individual diatom taxa to hydrological changes (see Round et al., 1990), by the presence of a particular pollutant or by the anthropogenic inputs of nutrients (see Sullivan, 2000). This agreed with the characteristics of the study area, which presented strong hydrological changes as a consequence of the influence of meteorological parameters, protection structures, river discharges and sewage outfalls.

It could be concluded that the observed structure of the planktonic communities largely reflected the effects of human influence along the Casa CaiadaRio Doce coastal zone. Thus, the dominance of some phytoplankton taxa, together with the low values for numbers of species, diversity and equitability indicated a stressed environmental condition. Although this was the general condition for the study area, the sheltered zone (landwards of the breakwaters) and, in particular, the shallowest Rio Doce bay (bay 3), which was under the direct influence of domestic sewage outfalls and the Paratibe river, were the areas presenting the worst environmental conditions during the wet season and consequently the most conditioned planktonic communities.

\section{RESUMO}

Foi realizado um estudo sobre a estrutura das comunidades planctônicas ao longo das praias de Casa Caiada e Rio Doce (Pernanbuco, Brasil). A área de estudo sofre grande influência antrópica onde as condições ambientais são controladas pela presença de estruturas costeiras, reduzindo a 
intensidade da circulação neste ambiente; e pelos efluentes clandestinos de esgoto que aportam águas poluídas para dentro do sistema protegido. Os resultados obtidos indicam que nas zonas protegidas as águas apresentam alta turbidez, temperaturas elevadas, salinidades reduzidas e altas concentrações de nutrientes e oxigênio. Estas condições são responsáveis pela redução da diversidade do plâncton e pelo aumento da biomassa das espécies mais resistentes. As diferenças registradas com respeito a áreas similares, porém não impactadas, parecem indicar que a estrutura planctônica pode ser usada como um indicador da qualidade ambiental, sugerindo uma baixa qualidade das praias em estudo.

\section{REFERENCES}

Boltovskoy, D. (1981), Atlas del zooplancton del Atlántico Sudocidental y métodos de trabajos con el zooplancton mariño. Mar del Plata: INIDEP.

Cristi, W. S. (1986), Marine fauna and flora of Bermuda: A systematic guide to the identification of marine organisms. New York: Wiley-Interscience Publications.

Desikachary, T. V. (1959), Cyanophyta. New Delhi: Indian Council of Agricultural Research.

Diretório de Hidrografia e Navegação-DHN (2000), Tábuas de Marés. Porto do Recife, DG-6-34.

Eskinazi, L. E. (1970), Estudo da plataforma continental na área do Recife (Brasil). IIIa Diatomáceas do fitoplâncton. Trabalhos do Instituto de Oceanografia da Universidade Federal de Pernambuco, 9/11, 159-172.

Eskinazi, L. E. and Koening, M. L. (1985/86), Distribuição das diatomáceas (Bacillariophyceae) na área de Suape (Pernambuco-Brasil). Trabalhos do Instituto de Oceanografia da Universidade Federal de Pernambuco, 19, 73-100.

Eskinazi, L. E. and Satô, S. (1966), Contribuição aos estudos das diatomáceas da praia de Piedade. Trabalhos do Instituto de Oceanografia da Universidade Federal de Pernambuco, 5/6, 73-114.

Eskinazi, L. E.; Silva-Cunha, M. G. G.; Koening, M. L.; Macêdo S. J. and Costa, K. M. P. (1997), Variação espacial e temporal do fitoplâncton na plataforma continental de Pernambuco - Brasil). Trabalhos do Instituto de Oceanografia da Universidade Federal de Pernambuco, 25, 1-16.

Fernández, E.; Cabal, J.; Acuna, J. L.; Bode, A.; Botas, A. and Garcia-Soto, C. (1993), Plankton distribution across a slope current-induced front in the southern Bay of Biscay. Journal of Plankton Research, 15 : (6), 619-641.
Gómez-Erache, M. W.; Norbis W. and Bastreri, D. (2000), Wind effect as forcing factor controlling distribution and diversity of copepods in a shallow temperate estuary (Solis Grande, Uruguay). Scientia Marina, 64 : (1), 87-95.

Grasshoff, K.; Emrhardt, M. and Kremling, K. (1983), Methods of Seawater Analysis. New York: Verlag Chemie..

Gusmão, L. M. O.; Neumann Leitão, S.; Nascimento Vieira, D. A.; Silva, T. A.; Silva, A. P.; Porto Neto, F. F. and Moura, M. C. O. (1997), Zooplâncton oceânico entre os estados do Ceará e Pernambuco, Brasil. Trabalhos do Instituto de Oceanografia da Universidade Federal de Pernambuco, 25, 17-30.

Haikui, H. and Jiachong, Z. (1998), Evaluation of the pollution in lake Dianch with zooplankton as indicator. Chinese Journal of Environmental-ScienceBeijing, 13 : (3), 33-36.

Hasle, R. G. (1983), The current status of the diatoms genus Coscinodiscus Ehrenberg 1939. Bot. Mus. Rapp, 33, 27-32.

Hidrodinâmica e Sedimentologia da praia de Casa Caiada-PE, Brasil. Master in Physical Oceanography, Universidade Federal de Pernambuco, Recife, Brasil.

Khalil, M. and El-Rahman N. A. (1997), Abundance and diversity of surface zooplankton in the Gulf of Aqaba, Red Sea, Egypt. Journal of Plankton Research, 19, 927-936.

Koening, L. M.; Eskinazi Leça, E.; Neumann-Leitão, S. and Macedo, J. S. (2003), Impacts of the construction of the Port of Suape on phytoplankton in the Ipojuca River estuary (Pernambuco-Brazil). Brazilian Archives Biology Technology, 46 : (1), 73-81.

Koening, M. L. and Eskinazi L. E. (1991), Aspectos quantitativos do fitoplâncton na área estuarina de Suape (PE). Encontro Brasileiro de Plancton, 4, 36-55.

Kokuirkina, E. N. and Mikaelyan, A. S. (1994), Composition and distribution of picophytoplankton on the open area of the Black Sea in winter. Okeanologiya, 34 : (1), 67-72.

Lange, C. B.; Hasle, G. R. and Syvertsen, E. E. (1992), Seasonal cycle of diatoms in the Skagerrak, North Atlantic, with emphasis on the period 1980-1990. Sarsia, 77, 173-187.

Licandro, P. and Ibanez, F. (2000), Changes of zooplankton communities in the Gulf of Tigullio (Ligurian Sea, Western Mediterranean) from 1985 to 1995, Influence of hydroclimatic factors. Journal of Plankton Research, 22 : (12), 2225-2253.

Linden, O.; Linden, O.; Ganning B. and Lindestrom, L. (1992), Studies on plankton, primary production and fish in the inner Brunei Bay. Marine Research Indonesian, 28, 55-79.

Linton, D. M. and Warner, G. F. (2003), Biological indicators in the Caribbean coastal zone and their role in integrated coastal management. Ocean and Coastal Management, 46, 261-276. 
Matsumura-Tundisi, T. (1986), Latitudinal distribution of Calanoida copepods in freshwater aquatic system of Brazil. Revista Brasileira de Biologia, 46 : (3), 527-553.

Moura, R. (1992), Biomassa, produtividade primária do fitoplâncton e alguns parâmetros ambientais da baia de Tamandaré (PE). Master in Biologic Oceanography, Universidade Federal de Pernambuco, Recife, Brasil.

Muller-Melchers, F. C. and Ferrando, H. J. (1956), Técnicas para el estúdio de las diatomáceas. Boletim do Instituto Oceanográfico, 7, 151-160.

Nascimento-Vieira, D. A.; Vieira, H. L. F. and Lima, T. V. C. (1985/86), Zooplâncton da região costeira do estado de Pernambuco. Trabalhos Oceanográficos da Universidade Federal de Pernambuco, 19, 55-72.

Neumann-Leitão, S. N.; Gusmão, L. M. O.; NogueiraParanhos, J. D.; Nascimento-Vieira, D. A. and Paranaguá, M. N. (1994/95), Zooplâncton da área estuarina do Rio Formoso-PE (Brasil). Trabalhos Oceanográficos da Universidade Federal de Pernambuco, 23, 55-64.

Neumann-Leitão, S. N.; Gusmão, L. M. O.; NogueiraParanhos, J. D.; Nascimento-Vieira, D. A. and Paranaguá, M. N. (1991/93), Zooplâncton da plataforma continental norte do estado de Pernambuco (Brasil). Trabalhos Oceanográficos da Universidade Federal de Pernambuco, 22, 97-116.

Newell, G. E. and Newell R. C. (1963), Marine plankton: practical guide. London: Hutchlson Educational.

Omori, M. and Ikeda T. (1984), Methods in marine zooplankton ecology. New York: Wiley-Interscience Publication.

Ottman, F. T.; Okuda, T.; Cavalcante, L.; Silva, O. C.; Araújo, J. V. A.; Coêlho, P. A.; Paranaguá, M. N. and Eskinazi L. E. (1965/66), Estudo da Barra das Jangadas - Parte V - Efeitos da poluição sobre a ecologia do estuário. Trabalhos do Instituto de Oceanografia da Universidade Federal de Pernambuco, 7/8, 7-16.

Paranaguá, M. N. (1966), Sobre o plâncton da região comprendida entre $3^{\circ}$ Lat $\mathrm{S}$ e $13^{\circ}$ Lat $\mathrm{S}$ ao largo do Brasil. Trabalhos do Instituto de Oceanografia da Universidade Federal de Pernambuco, 5/6, 125-39.

Paranaguá, M. N. (1967/69), Estudo da Plataforma Continental na área do Recife (Brasil) IIIb. Composição e variação do zooplâncton. Trabalhos Oceanográficos da Universidade Federal de Pernambuco, 18, 193-206.

Paranaguá, M. N. (1985/86), Zooplankton of the Suape area (Pernambuco-Brazil). Trabalhos Oceanográficos da Universidade Federal de Pernambuco, 19, 113-124.
Paranaguá, M. N.; Nascimento, D. A. and Macedo, S. J. (1979). Estudo Ecológico da região de Itamaracá, Pernambuco, Brasil. II. Distribuição do zooplâncton no estuário do rio Igarassu. Trabalhos Oceanográficos da Universidade Federal de Pernambuco, 14, 65-92.

Passavante, J. Z. O. (1979), Contribuição dos dinoflagelados da plataforma continental de Pernambuco (Brasil). Trabalhos Oceanográficos da Universidade Federal de Pernambuco, 14, 31-54.

Pereira, L. C. C. (2001), Procesos litorales a lo largo de las playas de Casa Caiada y Rio Doce, Olinda-PE (Brasil): Implicaciones para Gestión Costera. $\mathrm{PhD}$ Thesis, Universitat Politècnica de Catalunya, Barcelona, Spain.

Pereira, L. C. C.; Coutinho, P. N.; Macêdo, S. J. and Costa, R. A. A. M. (1996), Efeitos de estruturas de proteção costeira nas praias de Casa Caiada e Rio Doce - PE, Brasil. Trabalhos Oceanográficos da Universidade Federal de Pernambuco, 24, 19-37.

Pereira, L. C. C.; Jiménez, J. A.; Gomes, P. B.; Medeiros, C. and Costa, R. A. A. M. (2003a), Effects of sedimentation on scleractinian and actinian species in artificial reefs at the Casa Caiada beach (Brazil). In: Klein, A. et al. (Ed.). Brazilian Sandy Beaches: Morphodynamic, Ecology, Use, Hazards and Management. Journal of Coastal Reserach, SI (35), 418-425.

Pereira, L. C. C.; Jiménez, J. A. and Medeiros, C. (2003b). Environmental degradation of the littoral of Casa Caiada and Rio Doce, Olinda-PE (Brazil). In: Klein, A. et al. (Ed.). Brazilian Sandy Beaches: Morphodynamic, Ecology, Use, Hazards and Management. Journal of Coastal Reserach, SI (35), 502-508.

Pereira, L. C. C.; Medeiros, C. and Freitas, I. C. (2000), Effects of breakwaters on the morphology and sediment distribution at Casa Caiada Beach, OlindaPE (Brazil). In: Redondo, J. M. and Babiano, A. (Eds.). Turbulent diffusion in the environment. Madrid: Fragma. pp. 209-216.

Pereira, L. C. C.; Medeiros, C.; Jiménez, J. A. and Costa, R. A. M. [2005], Topographic changes in two highly sheltered beaches, Casa Caiada and Rio Doce -PE (Brazil). In: International Coastal Symposium, 8., Journal of Coastal Research, SI 39. Proceedings... [In press].

Pielou, E. C. (1969), An introduction to mathematical ecology. New York: Wiley Interscience.

Pielou, E. C. (1977), Mathematical ecology. New York: John Wiley and Sons.

Prescott, G. W. (1975), Algae of the western great lakes area. Dubuque: Brown Company Publishers.

Raymont, J. E. G. (1983), Plankton and productivity in the Oceans, $2^{\text {nd }}$ ed. Pergamon Press. 
Rosenstrom, U. and Lepisto, L. (1996), Phytoplankton indicator species of different types of borcal lakes, Archive fuer Hydrobiologie Supplementb, 116, 131-140.

Round, F. E.; Crawford, R. M. and Mann, D. G. (1990), The diatoms: Biology and Morphology of the genera. Cambridge: Cambridge University Press.

Shannon, C. E. (1948), A mathematical theory of communication. Bell System Technical Journal, 27, $379-423$.

Shushkina, E. A. and Vinogradov, M. E. (1992), Vertical distribution of zooplankton in the Guaymas Basin (Gulf of California). Okeanologia, 32 : (5), 881-887.

Silva, T. A.; Neumann-Leitão, S.; Schwamborn, R.; Gusmão, L. M. O. and Nascimento-Vieira, D. A. (2003), Diel and seasonal changes in the macrozooplankton community of a tropical estuary in Northeastern Brazil. Revista Brasileira de Zoologia,. 20 : (3), 1-11.

Stemberg, R. S. and Miller, E. K. (1998), A zooplankton N:P ratio indicator for lakes. Environmental monitoring and assessment Program (EMAP), $\mathbf{5 1}:$ (1-2), 29-51.

Strickland, J. D. H. and Parsons, T. R. A. (1968), The Practical Handbook of Seawater Analysis. Bulletin Fisheries Research Board of Canada, Ottawa, 167, 1-311.

Strickland, J. D. H. and Parsons, T. R. A. (1972), Manual of Seawater Analysis. Bulletin Fisheries Research Board of Canada, Ottawa, 125, 1-205.

Sullivan, M. J. (2000), Applied diatom studies in estuaries and shallow coastal environments. In: Stoermer, E. F. and Smoll, J. P. (Eds.). The diatoms: applications for the environmental and earth sciences. Cambridge: University Press Cambridge. pp. 334-351.

Thomas, C. R. (1997), Identifying marine phytoplankton. San Diego: Academia Press.

Todd, C. D. and Laverack, M. S. (1991), Coastal Marine Zooplankton: A practical manual for students. Cambridge: Cambridge University Press.

Totti, C.; Civitarese, G.; Acri, F.; Barletta, D.; Candelari, G.; Paschini, E. and Solazzi, A. (2000), Seasonal variability of phytoplankton populations in the middle Adriatic sub-basin. Journal of Plankton Research, 22 : (9), 1735-1756.

Villa, H.; Quintela, J.; Coêlho, M. L.; Icely, J. D. and Andrade, J. P. (1997), Phytoplankton biomass and zooplankton abundance on the south coast of Portugal (Sagres), with special reference to spawning of Loligo vulgaris. Scientia Marina, 61 : (2), 123-129.

Villate, F. (1997), Tidal influence on zonation and occurrence of resident and temporary zooplankton in a shallow system (Estuary of Mundaka, bay of Biscay). Scientia Marina, 61 : (2), 173-188.
Webber, D. F. and Webber, M. K. (1998), The water quality of Kingston Harbour: evaluating the use of the planktonic community and traditional water quality indices, Chemistry and Ecology, 14, 357-74.

Received: September 22, 2003; Revised: July 19, 2004; Accepted: July 11, 2005. 